\title{
Slyusarenko V. \\ STUDY OF FUNCTIONS OF STATE, BUSINE55, THIRD SECTOR AND PRINCIPLES OF THEIR INTERACTION DIRECTED ON ACHIEVEMENT OF EFFECTIVE SOCIETY
}

Проведено аналіз функиій, що виконують три сектора в суспільстві: держава, бізнес та третій сектор. Розглянуто принципи побудови відносин між ними та принщипи їх взаємодії, при яких досягається їх ефективне виконання. Доведено, що застосування розглянутих принципів: обопільної довіри та прозорості у відносинах; верховенства права; дотримання прав людини, чесної конкуренції в економічному $і$ соціальному розвитку; взаємного визнання потреб, інтересів та можливостей сторін дозволить украӥнському суспільству стати ефективним.

Ключові слова: тристоронне партнерство, трипартизм, ефективне суспільство, ефективне виконання функиій, обопільна довіра та прозорість.

\section{Introduction}

On the modern stage of the development of Ukraine a requirement in new public relations for the achievement of effective society appeared. It would be a display of more equal partnership relations between the three sectors in society than the prevalence of one over the other, or absorption of one another.

According to Hawrylyshyn B., the community members of «the third sector» can create an effective society. He also emphasized that this transformation must take place not with the help of force, not in revolutionary, but evolutionary way, and its main driving force will be the active part of the population, involved in the third sector. Economic growth of the society depends primarily on every individual. Society is effective when every member does his job qualitatively and receives remuneration in the form of moral and material satisfaction.

\section{The object of research and its technological audit}

The object of the research is the cooperation between the three sectors in society and the principles of their cooperation directed on the construction of the effective community.

This can be achieved only through effective cooperation between the state, the business and the public organizations.

We think that the work of all the sectors: the state, the business, the third sector, and the principles of their cooperation should be based on the completion of their inherent natural functions.

\section{The aim and objectives of research}

The aim of research is to analyze the functions that are actually performed with the three sectors and the principles on which the relationships between them are developed.
Their condition can play a positive role by the mechanism of facilitating and accelerating of the development of the country, which is the main task of the state and the negative role, in which the content of the relationships «state - business - third sector» is a mechanism of the inhibition or even of the suppression of social development.

The objectives of the article are:

1. To research the importance of the partnership between the state, the business and the third sector for the effective development of society.

2. The cooperation in the partnership, which should be based on the principles of mutual interests and benefits in solving the general and urgent problems.

3. To take out the basic concepts which define the theoretical basis of the effective cooperation.

4. To describe the main types of relationships between the state, the business and the third sector, which were formed because of the evolution in Ukraine.

5. To take out the principles on which their relationships are effective and the result of which is an effective economy and effective society.

\section{Research of existing solutions of the problem}

The analysis of publications of the scientists who were engaged in the cognate researches gives us a possibility to organize them in following way: [1] found out the issue of social responsibility in the context of human development, [2] explored questions of the interaction between authority, business and society in market relations, [3] worked on the efficiency of society, [4] dedicated his publication to the mechanisms of interaction between state, business and non-governmental non-profit sector in the solving of the social problems. In the works [5-10] the socio-political partnership in the Ukrainian context is described.

However, there are unresolved components of the general problem of effective interaction between the state, 
the business and the third sector, which are directed to improve the efficiency of Ukrainian society.

\section{Method of research}

To achieve the objectives we used the following methods: empirical analysis and synthesis, logic synthesis, analogy, comparative comparison.

\section{Research results}

The situation in the economic, political, ecological and social areas is extremely difficult. That is why the country needs a total transformation - a fundamental change in the structure of authority and in the economic and social systems. In these conditions, it is necessary to answer the questions how to do it and who will do it? We should not rely on the authority because its representatives do not know how to act, or do not interested in such changes. We also cannot rely on business, because the bosses are merging with the authority and pursues their own interests. Nevertheless, representatives of public organizations can do that, moreover, the principles of their work organization look like the business organizations [1].

Historically the intersectoral interaction was one-sided and manifested in the full control by the state structure over the other two sectors. However, the situation changes more and more in the direction of public activity. In this situation, the state cannot carry out the hypercontrol. The situation needs to be changed because the business is merging with the state. That is why, there is a need to develop relations on the new principles of the effective society formation. Taking out the new principles is not possible without the analysis of what has happened at this stage and the researching of the functions, which are performed by the state, the business and the third sector in society.

We have systematized the functions of the three sectors and described what they do in the community on the Fig. 1.

So, having the common features in the country, these sectors are beginning to assume the responsibilities more than they could do, hoping that representatives of the other sector will realize the inherent function. For the purpose of the sectors in the country, they do what the society expects from them and develop themselves staying unengaged, and we need to agree the principles on which they build the relationships.

Moreover, the distinctive features are still non-realized or even are fined because we do not have neither power nor motivation for their implementation as all the efforts get away to «drag the coverlet» and reduce the liability.

On this background, the need for partnerships between sectors is enhanced with the administrative-territorial reforms. One of the conditions of which is that the main burden is transferred to the municipal authorities with reduced funding from the state budget. Thus, reforms stimulate to activate internal resources of the territory [2]. The reform process is affected with a growing pluralism of public institutions. The need for changing of the management system appears that will be based on horizontal relations in the local community and the global information transparency of their operation. These conditions stimulate the local governments, public organizations and business to realize that they are responsible for the ef- fective functioning of the local community as they are merged its territorial problems and therefore they are in functional and resource interdependence. Thus inefficiency of the existing relationships needs the transformation, in other words more effective cooperation for effective development of the local community [3].

In the recent years, the willingness for interaction of the state representatives mostly of local authorities with the public organizations and business has improved, that is showed in the active involvement of their representatives in the various fields of economy, culture and implementing of the local initiatives focused not only on a particular aspect of social life, but also in the selection of the best partners for the purpose of effectiveness and efficiency of the resources usage.

Therefore, for understanding, what defined functions are really fulfilled by each of the sectors, and where the gaps are or taking on additional duties, we need to analyze them by the indicators that characterize their performance.

That is why it is necessary to use the principle of transparency, which is preferably implemented using modern innovative technologies with the help of which it is possible to generalize the work of all sectors and present the work and experiences posted in the Internet on the online platforms. Such online information gives the possibility of building partnerships and to explore the common ground. With the help of the online mode you can work out previous agreements and initiatives, speak out constructively about the implementation of each of the sectors of their legal and natural features and where are the gaps.

This resource allows us to develop confidence in the public authorities, the work of business and public organizations. That's why, the use of advanced new technologies is the main instrument of transparency: the sites, the regular public reporting, preparation and submission of electronic platforms are in the public domain, «Open Budgets» transparent procurement at the budget cost, continual correspondence and carrying out someone's duties through the «Open City» and the centers of administrative services. In addition, effective instrument for improving the mutual trust is the interaction of the state, the business and the third sector with media and public events involving these three sectors.

The civil society, which is both a source of funding and intangible support and beneficiary of the non-profit organizations that in their turn inform it about their operations, also should operate in a system of transparency and accountability. As if only one trusts, and the other uses that trust, the interaction stops [4].

Three basic conditions help in mutual trust of the parties or actually establish strategies of behavior in the partnerships. The first is the presence of so-called third (neutral) persons whose function is reduced to facilitate the interaction. The second condition of the trustful relationships is the nature of communication links of the cooperating parties. First of all, the availability of information for the each partner about the interaction of each other and adjusted information exchange. The third condition that contributes to confidence is personal characteristics of the participants of the interaction and the availability of the informal relations. Using this approach for the tripartite partnership, we note that the role of the public organizations in this relationship play a role of a mediator. 


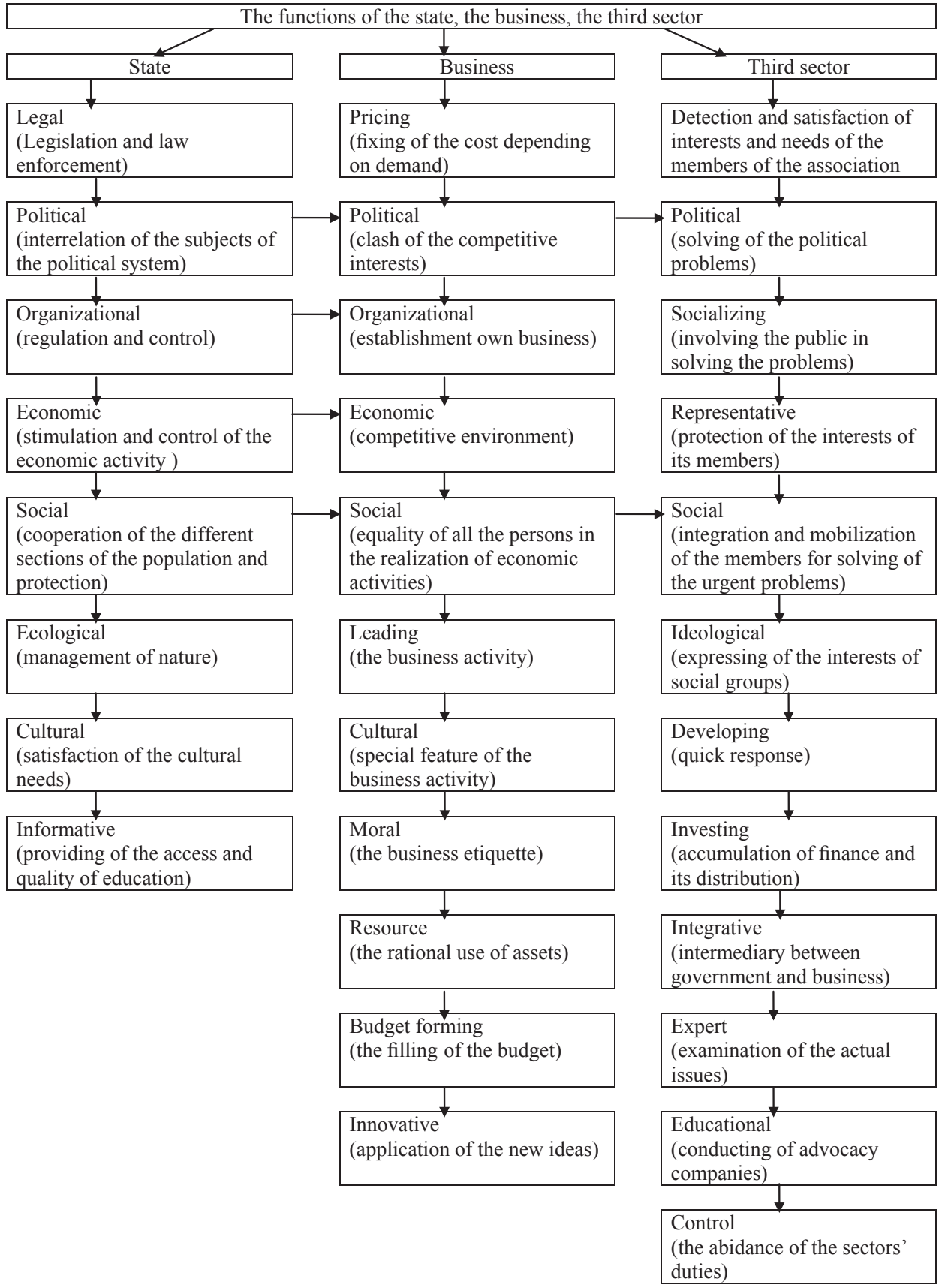

Fig. 1. Functions of three sectors

During the organization of the symmetric communication, subjects receive the necessary information from each other, and the third condition is carried out by the local social networking communities.

To the principals, based on the creation of the trust, we include:

- Honest and open communication without the distortion of the information.

- Ability to listen to someone's opinion, even if you

do not agree with it.

- Observance of promises and commitments.

- Interaction with others and mutual assistance [5].

To the destroyer of the trust we include such principals as:

- The bigger interest in their own welfare than in the achievement of a common goal.
- One of the participants avoids taking responsibility for own actions or for the development of the society - One of the participants makes the wrong conclusions about others without checking the facts.

In addition, lack of transparency and accountability of the public sector and the third sector reduces the trust to business organizations and donor organizations; it becomes difficult to attract the volunteers, partners, donors and sponsors for realization of projects relevant for the territory.

The principle of the trust is the main one, because the situation is complicated with the absence of the level of confidence of the Ukrainian society to the state.

The principle of transparency must be observed with the commercial companies too, because the society needs to be aware of their social and financial statements, as well 
as be able to develop joint programs considering their own interests. Besides the openness, the partnership necessarily involves feedback. The openness, lack of manipulative technologies are possible only in the presence of feedback that allows you to develop common strategies to achieve this goal in constructing of the partnerships where the information exchange between partners is realized by the using of existing technologies [6].

In order to achieve effective performance of the functions by the each sector, the agreement should be recorded on the paper, signed by all the members of the tripartism. Such arrangements are easier to control and they are more transparent, without double standards of the understanding of the spoken phrases.

The mechanism of the interaction between the state, the business and the public society is based on the optimal using of such system principals:

1. Achievement of the consensus of the interests of the state, the business and the third sector during the public debate about the identification of the main areas of the economic and social strategy of the state.

2. The institutionalization of the relationships between the business structures, society and government through the strengthening of the role of community councils, supervisory boards, lobbying agencies, self-regulatory organizations of the businessmen, realization of the relevant programs for the community.

3. Participation of the budget-formed and large companies in the social and economic life of the community through the institute of public private partnerships and other partnership models.

4. Transparencies of the relationships between state and business and civil society.

5. Democratization of the processes of the making strategic decisions.

6. Diversification of the business, state and third sector responsibility $[7,8]$.

Indicated principles and implementations of the most important, economic function of performing by three sectors implement the model «competitive economy - effective citizens - effective state - effective society». The development of this mutually beneficial policy is possible only in the process of constructive open dialogue between the state, business and civil society. Removing any of these parties from the dialogue at once leads to imbalance of national socio-economic system.

As part of the economic dialogue, business gets the recognition that it is an equal partner of creation of the future of the nation. It encourages the businesses representatives to analytical study of the situation in their professional activity at the particular area and in the national economy realizing the qualified proposals for the construction of economic policy.

On this background, the principle of dialogue, realized as an integral part of economic development, allows us to establish an effective system for ensuring compliance of the social standards with state [9].

Clear economic dialogue between authority and business significantly reduces the risk of doing business by increasing the predictability of public policy as an important factor in the functioning of business environment.

Economic dialogue is the basis for creating favorable conditions for the development of priority sectors of industry not because of preference of one or other random events, but through the formation of complex of micro and macroeconomic conditions in the policy guidance for the development of such industries.

Economic dialogue plays the role of a «filter» to separate unreasonable for society innovations, including - those with corporate lobbyist origin and not directed to preserve the ecology [10].

In Ukraine increasing effectiveness of the dialogue is possible only in case of its reaching a wider range of issues relating to strategic guidelines of the domestic business, the awareness of the close link between this development and the conditions of its functioning in economy, transparency and simplicity of legislation that control their interaction, ecological aspects of territorial development and openness of budgets [11].

As we have mentioned above, the economic dialogue should be based on three basic principles that should be publicly declared and documentary secured by all the parties:

1. Business should be law-abiding and responsible in the social and ecological areas.

2. The dialog should take into account the necessity to create the favorable conditions for the functioning of business.

3. The state should be a guarantee of stable and transparent conditions in which the business operates and gets the profit.

4. The representatives of the public organizations, independent experts should control and monitor the effectiveness of the agreements [12].

It is extremely important principle of organic unity of the legal aspect in the relationship of tripartism; it relates the human rights situation of mutual dependence on social efficiency of social rights of all system of civil society factors and the society on the condition of law social efficiency [13].

So in the realizing of the functions in a constructive partnership of government institutions, business and the third sector on the principles of parity on solving urgent problems of local communities, in general, we understand the development of constant forms of equal dialogue based on the following principles: mutual recognition of the interests of the parties; openness and trust; social justice during the regulating of the interests and actions; mutual responsibility; mutual control; environmental relations.

To achieve such a partnership you have to pass the several stages:

1. Formation of a common goal.

2. Planning of the events.

3. Construction of the relationships.

4. Management of the partnership.

5. Development of the ability to solve problems.

6. Searching and finding out the compromise in solving the disputable and conflict issues.

7. Development of the methods for assessing interaction [14].

The principles that we have mentioned above can be realized with joint activities, in which partners learn to speak the «same language», to overcome antagonism.

Carrying out of the functions by three sectors will become effective when many people and representatives of all sectors will support the mentioned principles [15]. Since an incompliance with at least one of them of these principles leads to discouragement «all to all» and become destructive tendencies in the transformation of society. 
Summing up, we can make a conclusion that the problem of interaction between the state, business and civil society is crucial in the life of any democratic country [16]. Moreover, development prospects are opened only when the state, business and civil society not only start a dialogue, but also establish a stable interaction between each other, the active participation of civil society for both state and business to realize requests and interests of the people [17].

Combining the resources of the state and the business community is necessary for the development of society, the state and the business [18]. The tripartite partnership between, the business and the third sector will strengthen the institutions of state and private property, increase the level of trust in the state, change the image of the business in the eyes of people in a positive way, voluntary business participation in satisfaction of social requests, its responsible attitude to the issue of sustainable development [19].

From the foregoing the basis of the partnership, directed on creation of the effective public, is transparency of the relations between the third sector, state, business and the principles of democracy, rule of law, human rights, fair competition in economic and social development, mutual recognition of the needs, interests and possibilities of the parties. Created on the following principles, relations of the three sectors in the country, as at the micro and at the macro levels lead to efficiency of the community and become the key to effective society [20].

\section{SWOT analysis of the research results}

Strengths. The positive part is the creating of tripartism on the conditions of mutual trust and transparency in the relationships; rule of law; human rights, fair competition in economic and social development; mutual recognition of the needs, interests and possibilities of the parties will allow every participant of the relationships to perform their functions in a clear and agreed frameworks, to change them quickly responding to changes in society if it is necessary.

Weaknesses. Relations between the state, the business and the third sector, which are built on the principles described in this article, may at the beginning slow down the transformation process, as each of representatives of tripartism needs to get skills of the creation of the cooperation, especially monitoring; the use of the innovative instruments; constructive dialogue; knowledge of the legal framework.

Opportunities. The following prospects of the research lies on the fact of studying in detail the forms and instruments using which the partnership of state, business and the third sector will be most effective using the proposed principles for the operational impact on its functions.

Threats. Threats to organize a constructive and effective partnership, proposed on the principles, are the human factor and the solid disbelief in the possibility of changes that do not motivate participants of the tripartism to get the relevant skills and to be active participants of the process of the transformations. Accordingly, without the active participation of a large number of Ukrainians in the transformation processes we will observe distortions of the changes and the further impoverishment of the nation.

\section{Conclusion}

1. We have proved the importance of the partnership between the state, the business and the third sector for effective development of society.

2. We have determined that the interaction in the partnership, which should be based on the principles of mutual interests and benefits in solving general and urgent problems.

3. We have derived the basic concepts that define the theoretical basis of effective cooperation.

4. We have characterized the main types of relations between the state, the business and the third sector, which were formed through evolution in Ukraine.

5. We have derived the principles on which their relationships are effective and which result is an effective economy and effective society.

\section{References}

1. Amosha, O. Sotsialna vidpovidalnist $\mathrm{v}$ kontekst i rozvytku liudskoho potentsialu [Text] / O. Amosha, O. Novikova // Derzhava i suspilstvo. - 2011. - P. 122-127.

2. Berzhanir, A. International experience ensure interoperability between business and government in economic systems [Text] / A. Berzhanir // Bulletin of Donetsk National University. Series C. Economics and Law. - 2015. - № 1. - P. 32-35.

3. Berzhanir, A. Stanovlennia vzaiemodii vlady, biznesu i suspilstva v rynkovykh umovakh [Text] / A. Berzhanir // Stalyi rozvytok ekonomiky. - 2013. - № 3. - P. 18-21.

4. Havrylyshyn, B. Do efektyvnykh suspilstv [Text]: Dopovid Rymskomu Klubovi / B. Havrylyshyn. - Ed. 3. - Kyiv: PULSARY, 2009. - 248 p.

5. Dumnazev, D. A. Mechanisms of interaction between the government, business and non-profit sector in addressing social problems [Electronic resource] / D. A. Dumnazev // Sovremennye tehnologii upravleniia. - 2013. - № 2 (26). - Available at: \www/URL: http://sovman.ru/article/2602/

6. Lobanova, A. Sotsialno-politychne partnerstvo u konteksti ukrainskykh realii: postanovka problemy [Text] / A. Lobanova // Metodolohiia, teoriia ta praktyka sotsiolohichnoho analizu suchasnoho suspilstva. - 2010. - Vol. 16. - 716 p.

7. Evdokimov, I. Gosudarstvenno-obshchestvennoe partniorstvo $\mathrm{v}$ reshenii problem retsidivnoi prestupnosti [Text] / I. Evdokimov // Bezopasnost Evrazii. - 2010. - № 2. - P. 531-546.

8. Zadorin, I. Dinamika razvitiia i tekushchee sostoianie sektora NKO v Rossii [Electronic resource] / I. Zadorin // Analiticheskii obzor № 3 po rezul'tatam analiza gosudarstvennoi statistiki i baz dannyh NKO. - 2013. - Available at: \www/URL: http:// www.zircon.ru/upload/iblock/6d1/090206.pdf

9. Kislitsyn, S. Formy i metody vzaimodeistviia vlasti, biznesa i grazhdanskogo obshchestva v sovremennyh usloviiah [Electronic resource] / S. Kislitsyn, N. Reviagina, G. Kumov // Politicheskie instituty, protsessy i tehnologii. - 2016. - № 4. Available at: \www/URL: http://www.journal-nio.com/index. php?option $=$ com_content\&view $=$ article\&id $=3833 \% 3 \mathrm{~A}-15 \&$ catid $=115 \% 3$ Aapr \& Itemid $=158$

10. Perekrestov, D. G. Korporativnaia sotsial'naia otvetsvennost' voprosy teorii i praktiki [Electronic resource] / D. G. Perekrestov, I. P. Povarich, V. A. Shabashev. - Akademiia Estestvoznaniia, 2004. - Available at: \www/URL: https://www.monographies.ru/ru/book/view?id=139

11. Kuznietsov, V. Kultura partnerstva yak kultura zhyttia [Text] / V. Kuznietsov // Bezopasnost Evrazii. - 2010. - № 2. - P. 7-52.

12. Petrov, A. Trehstoronnee vzaimodeistvie i sotrudnichestvo, TK RF i osnovnye printsipy sotsial'nogo partnerstva [Electronic resource] / A. Petrov // Kadrovik. Trudovoe pravo dlia kadrovika. - 2007. - № 11. - Available at: \www/URL: http://www.hr-portal.ru/article/trehstoronnee-vzaimodeystviei-sotrudnichestvo-tk-rf-i-osnovnye-principy-socialnogo 
13. Slyusarenko, V. Formation of mechanism of three-way partnership between government, business and public institutions [Text] V. Slyusarenko // Rehionalna ekonomika. - 2014. - № 1. P. 141-148.

14. Slyusarenko, V. Evolution conceptual-categorical apparatus of institute tripartite partnership between government business and the third sector [Text] / V. Slyusarenko // Visnyk Sumskoho derzhavnoho universytetu. Seriia: Ekonomika. - 2015. № 2. - P. 48-57.

15. Slyusarenko, V. Models of trilateral partnership interaction [Text]/ V. Slyusarenko // Socio-economic problems of the modern period of Ukraine. - 2016. - Vol. 1 (117). - P. 97-100.

16. Slyusarenko, V. Theoretical basis of institute tripartite partnership between government business and the third sector [Text] / V. Slyusarenko // Bulletin of Donetsk National University. Series C. Economics and Law. - 2015 - № 2 - P. 328-331.

17. Slyusarenko, V. Evolution of conceptual-categorical apparatus of tripartite partnership institute between government business and the third sector [Text] / V. Slyusarenko // Scientific Bulletin of Mukachevo State University. Series «Economics». 2016. - Vol. 1 (5). - P. 64-70

18. Spravitsia li gosudarstvo v odinochku? O roli NKO v reshenii sotsial'nyh problem [Text] // Reports to the XII International Scientific Conference of the National Research University «Higher School of Economics» on the problems of economic development and society, Moscow, April 5-7, 2011. - Moscow: Izdatel'skii dom Vysshei shkoly ekonomiki, 2011. - 56 p.

19. Tulchinskii, L. Biznes, gosudarstvo i obshchestvo v sovremenno Rossii [Text] / L. Tulchinskii // Upravlenie i vlast. - 2004. P. 277-301
20. Sanders, J. The New Zealand Nonprofit Sector in Comparative Perspective [Text] / J. Sanders, M. O'Brian, M. Tennant, S. W. Sokolowski, L. M. Salamon. - Wellington (New Zealand): Johns Hopkins Center for Civil Society Studies, Office for the Community and Voluntary Sector, Committee for the Study of the New Zealand Nonprofit Sector, 2008. - 52 p.

\section{ИССЛЕДОВАНИЕ ФУНКЦИЙ ГОСУДАРСТВА, БИЗНЕСА}

\section{ТРЕТЬЕГО СЕКТОРА И ПРИНЦИПОВ ИХ ВЗАИМОДЕЙСТВИЯ}

НАПРАВЛЕННЫХ НА ПОСТИЖЕНИЕ ЗФФЕКТИВНОГО ОБЩЕСТВА

Проведен анализ функций, которые выполняют три сектора в обществе: государство, бизнес и третий сектор. Рассмотрены принципы построения отношений между ними и принципь их взаимодействия, при которых достигается их эффективное выполнение. Доказано, что применение рассмотренных принципов: обоюдного доверия и прозрачности в отношениях верховенства права; соблюдения прав человека, честной конкуренции в экономическом и социальном развитии; взаимного признания потребностей, интересов и возможностей сторон позволит украинскому обществу стать эффективным.

Ключевые слова: трехстороннее партнерство, трипартизм, эффективное общество, эффективное выполнение функций, обоюдное доверие и прозрачность.

Slyusarenko Victoria, PhD, Associate Professor, Department of Accounting and Audit, Uzhgorod National University, Ukraine, e-mail: official@uzhnu.edu.ua, ORCID: http://orcid.org/0000-00019571-6877 